\title{
Behandlingsresistens ved immunterapi mot maligne svulster
}

\section{Immunterapi mot malignt melanom hos mus gir først respons, men senere resistensutvikling. Årsaken er en nyoppdaget mekanisme som kalles reversibel dedifferensiering.}

I en musemodell har man benyttet transplantasjon av cytotoksiske T-lymfocytter rettet mot kjemisk indusert malignt melanom for å studere utvikling av behandlingsresistens. Slik ble det avdekket en ny mekanisme for dette (1).

T-lymfocyttene var gjort reaktive mot tumorantigenet gp 100 ved hjelp av transgenmetodikk. Når melanomcellene som ble immunresistente, ble transplantert til nye mus, ble de igjen mottakelige for immunterapi, men bare forbigående. Effekten av immunterapien berodde på at gp100 var til stede. Nedregulering av dette antigenet skjedde uten celledelinger, men var assosiert med inflammasjon i tumor - mer spesifikt med sekresjon av inflammasjonscytokinet TNF$\alpha$. Humane melanomcellelinjer nedregulerte også målantigenet og ble resistente etter TNF- $\alpha$-behandling, mens ikke-melanocytt-

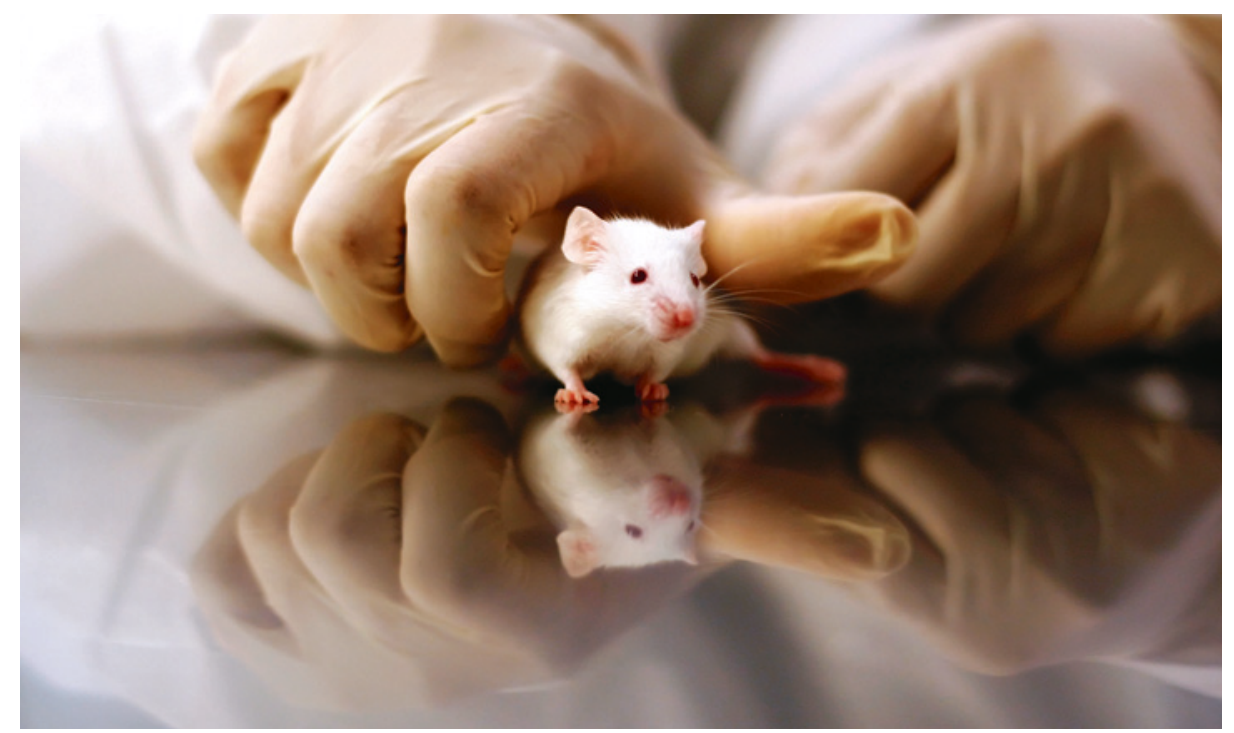

\section{Nye muligheter for stamcellemanipulering}

\section{En nyoppdaget signalmekanisme knyttet til adhesjonsproteinet E-selektin kan påvirke beinmargs- stamcellenes evne til å overleve cellegiftbehandling og bestråling.}

Stamceller finnes i cellulære nisjer, der nisjecellene regulerer stamcellenes celledeling, selvfornyelse og differensiering. Ved knoklenes indre overflate er stamcellene lokalisert nær osteoblaster og deler seg sjelden. Stamceller som er lokalisert nærmere margens blodårer, der de påvirkes sterkere fra andre nisjeceller, deler seg hyppigere.

I omfattende museeksperimenter har man nå funnet at E-selektin på blodårenes endotelceller kan signalisere til ligand(er) på stamcellene og dermed gi en sterk stimulus til celledeling (1). Mus som hadde endotel- celler uten E-selektin, eller villtypemus behandlet med en E-selektinantagonist, fikk sjeldnere stamcelledelinger, økt fornyelse av stamcellene og økt overlevelse etter behandling med cellegift.

- Disse funnene er svært interessante, men det er for tidlig å si noe om mulige kliniske anvendelser, sier professor Torstein Egeland ved Avdeling for immunologi og transfusjonsmedisin, Oslo universitetssykehus, Rikshospitalet. - $\AA$ «beskytte» de bloddannende stamcellene ved f.eks. cellegiftkurer og strålebehandling er viktig. Imidlertid har vi god erfaring med autolog stamcellestøtte, der pasientens egne stamceller tas ut og lagres i nedfryst tilstand før en behandling med sterke cellegifter eller stråling. De lagrede stamcellene tilbakeføres etter behandlingen. E-selektinantagonister skal derfor være svært effektive og sikre før de kan erstatte en så veletablert teknikk som autolog stamcellestøtte er, sier han. antigener ble oppregulert. Mekanismen omtales som reversibel dedifferensiering

- Denne studien er meget interessant, sier professor Johanna Olweus ved Seksjon for immunologi, Institutt for kreftforskning, Oslo universitetssykehus. - Forskerne bak studien konkluderte med at man for å unngå behandlingsresistens bør målrette immunterapien mot flere antigener. Dette er et viktig prinsipp for å begrense resistensutvikling, sier hun.

- Selv om musemodellen er elegant, er den kunstig, og det blir spennende å se om liknende funn kan gjøres hos mennesker. Hemming av effektene til TNF- $\alpha$ brukes i dag for å dempe autoimmune inflammasjonssykdommer. TNF- $\alpha$ kan virke både immunstimulerende og immunhemmende, og anti-TNF- $\alpha$ kan derfor tenkes å være et tveegget sverd i kreftbehandlingen. Kombinasjonsterapi med andre spesifikke immunblokkere er imidlertid lovende. Effektivt T-cellemediert drap av kreftceller kan også oppnås ved bruk av Tceller utstyrt med reseptorer som binder mål på kreftcellene med høy bindingsstyrke. Da må til gjengjeld målantigenet være selektivt uttrykt på cellene som kreften utgår fra, ellers vil man kunne få alvorlige bivirkninger, sier Olweus.

\section{Haakon B. Benestad}

h.b.benestad@medisin.uio.no

Universitetet i Oslo

\section{Litteratur}

1. Landsberg J, Kohlmeyer J, Renn M et al. Melanomas resist $\mathrm{T}$-cell therapy through inflammation-induced reversible dedifferentiation. Nature 2012; 490: 412-6.

- Å bruke E-selektinantagonister til å ekspandere stamcellepopulasjoner in vitro før en transplantasjon, uten at differensieringen igangsettes, kan være en mer tiltalende mulighet, fortsetter han. - Spesielt gjelder dette ved navlestrengsblodtransplantasjon, som kan være aktuelt der vi ikke finner en HLAidentisk giver for en vanlig beinmargstransplantasjon. Det er mindre strenge krav til HLA-matching ved bruk av navlestrengsblod, men antallet stamceller er ofte for lavt i én navlestrengsblodenhet, sier Egeland.

\section{Haakon B. Benestad}

h.b.benestad@medisin.uio.no

Universitetet i Oslo

\section{Litteratur}

1. Winkler IG, Barbier V, Nowlan B et al. Vascular niche E-selectin regulates hematopoietic stem cell dormancy, self renewal and chemoresistance. Nat Med 2012; 18: $1651-7$. 